on of the sexual homoeostat and certain prior energy requirements. Sexual maturity does not begin until a certain critical body weight is reached, and this is indicated in the diagram provided by Professor Crisp. In fact, the earlier age at which puberty occurs at the present time must be related to improved quantities and distribution of food supplies It is also clear from the diagram of the typical evolution of anorexia nervosa that the phobic avoidance of mature body weight produces a reduction below the $50 \mathrm{~kg}$ weight level at which this phase of development normally commences. Critical weight, and weight gain from the age of 9 is a preparation for a period of rapid cell growth, and the storage of cholesterol is necessary since this substance is a unique and important constituent of the plasma membrane of mammalian cells. A cell will not enter the mitotic cycle unless the cholesterol level required for development of the membranes of daughter cells is attained.'

Means for the integration and coordination of the functions of separate endocrine glands are provided at the pituitary level of the endocrine system, but interference with energy intake will reverse this normal process and retard aging. It is interesting to note that it has often been reported that the same negative emotions increase appetite and body weight in middle aged persons. ${ }^{2}$

Croydon CRO 7HL

M KeITh Thompson

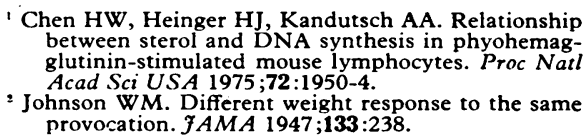

\section{Epileptic seizures in general practice}

SIR,-The findings of Dr D M G Goodridge and Dr S D Shorvon (3 September, p 641) may come as no surprise to general practitioners but will be valuable to hospital physicians in putting epilepsy into perspective. The results would have been more convincing, however, if the authors had described precisely how they axcluded anoxic seizures ${ }^{1}$ (nonepileptic convulsive syncope) and indicated whether or not they included anoxic-epileptic seizures" as "epilepsy." They excluded febrile convulsions (only in those aged between 12 months and 5 years, for reasons unexplained) but included fits after alcohol withdrawal; surely these fits comprise both "stress convulsions," genetically linked to febrile convulsions, ${ }^{3}$ and vagal convulsive syncope.

I do not think that it is sufficient for the diagnosis of epilepsy that it has been considered certain by a neurologist or a paediatrician. I have no reason to believe that our neurologists and paediatricians are less diagnostically alert than their southern counterparts, but nevertheless of 41 patients with reflex cardiovagal convulsive syncope recently studied $40 \%$ had been diagnosed as having epilepsy, $9 \%$ with enough confidence for each to be prescribed a mean of 1.8 antiepileptic drugs (unpublished data). The diagnosis was missed because, having excluded breath holding attacks or vasovagal syncope, sufficient attention was not paid to the provocation, to the heart stopping precipitating factors ${ }^{4}$-head bump, pain, fright, or surprise.

On being introduced to the ways of the vagus and the concept of reflex asystole, patients and parents ask "Why don't the doctors know about this ?" Those who write about the demography of epilepsy should make it crystal clear that they are cognoscenti and know the sheep from the goats.

\section{J B P STEPHENSON}

Fraser of Allander Unit,

Royal Hospital for Sick Children,

Yorkhill

Glasgow G3 8SJ

'Stephenson JBP. Reflex anoxic seizures and ocular compression. Dev Med Child Neurol 1980;22: 380-6.

Stephenson JBP. Febrile convulsions and reflex anoxic seizures. In: Rose FC, ed. Research progress in epilepsy. London: Pitman, 1983:244.

Friis ML, Lund M. Stress convulsions. Arch Neurol $1974 ; 31: 155-9$.

Braham J, Hertzeanu H, Yahini JH, Neufeld HN. Reflex cardiac arrest presenting as epilepsy. Ann Neurol $1981 ; 10: 277-8$

** We sent a copy of this letter to the authors, who reply below.-ED, $B M \mathcal{H}$.

SIR,-The problems of diagnosis in our study were discussed in detail, and we quite agree that anoxic seizures may be mistaken for epilepsy and that care should be taken to exclude this. The problem is perhaps greatest among children, and in the paper of Friis and Lund, which Dr Stephenson quotes, "stress convulsions" were identified in only $3 \%$ of 1250 patients with convulsive disorders.

Tonbridge,
Kent

D M G GOODRIDGE

S D SHORVON

National Hospital for Nervous Diseases,

Queen Square,
London WC1N 3BG

\section{Dihydrocodeine overdose treated with naloxone infusion}

SIR,-We would like to make several points in response to Dr Nancy Redfern's lesson of the week (10 September, p 751). Firstly, at least 1.2 to $1.6 \mathrm{mg}$ naloxone is required as an initial dose in severe opiate poisoning. ${ }^{1}$

Secondly, once the trends in the patient described were obviously downwards artificial ventilation should have been started. This would have been preferable to administering further doses of naloxone in an attempt to avoid intermittent positive pressure ventilation, which allowed the patient to reach the brink of respiratory arrest on two occasions. Earlier intermittent positive pressure ventilation would also have corrected the respiratory component of the acidosis, which was undoubtedly aggravating the hyperkalaemia, although reduction of the serum potassium to a safe level would probably still have required dialysis. In our view dialysis should have been considered when the serum potassium had risen to $5 \mathrm{mmol}(\mathrm{mEq}) / \mathrm{l}^{2}$ and certainly started when it was $7.4 \mathrm{mmol} / \mathrm{l}$. The delay allowed a rise to $8.2 \mathrm{mmol} / \mathrm{l}$, which may well have induced cardiac arrest in an already hypoxic myocardium. $^{3}$ (There is no mention of arterial oxygen pressure $\left(\mathrm{PaO}_{2}\right)$ or fractional inspired oxygen $\left(\mathrm{F}_{\mathrm{I}} \mathrm{O}_{2}\right)$ at any point in the text but, with the alveolar gas equation, an arterial carbon dioxide pressure $\left(\mathrm{PaCO}_{2}\right)$ of $14.3 \mathrm{kPa}$ corresponds to a $\mathrm{PaO}_{2}$ of about $4 \mathrm{kPa}$ when breathing room air.) Finally, it is important to note that the manufacturers of naloxone (Du Pont, UK) recommend that the drug be used with caution in the presence of myocardial irritability as ventricular tachycardia may be induced.

In summary, we feel that Dr Redfern was fortunate following her line of management in view of an inadequate sustained response to naloxone. We accept that this treatment has been used with success in other cases of opiate overdosage ${ }^{5}$ but failure is not an indication to soldier on seeking an effective dose; rather it is an indication for intermittent positive pressure ventilation.

I J GORDON

Whiston Hospital,

Prescot,

Merseyside L35 5DR

H L GORDON

Royal Liverpool Hospital,
Liverpool

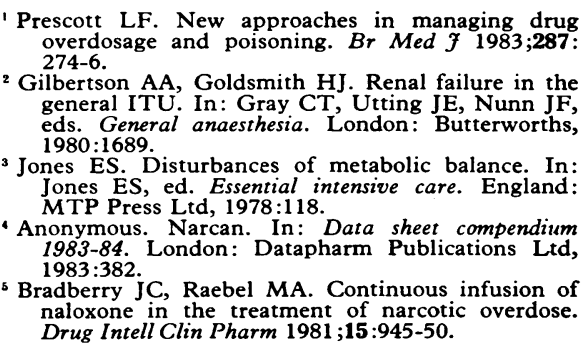

\section{Sickle haemoglobin and pregnancy}

SIR, - We would like to comment on the review by Dr Graham $R$ Serjeant on sickle haemoglobin and pregnancy (3 September, p 628). Women with both sickle cell trait and sickle cell disease should ideally be offered the facilities of genetic counselling and antenatal diagnosis, to which their condition so readily lends itself. Fetoscopy in the second trimester allows globin chain analysis of a fetal blood sample, ${ }^{1}$ while the newer techniques of chorionic biopsy and DNA analysis are applicable in the first trimester. ${ }^{2}$

We feel that it is dangerous to assume that women with sickle cell haemoglobin $\mathrm{C}$ disease (SC) have fewer problems in pregnancy than those with homozygous sickle cell (SS) disease although the unwary clinician may be lulled into a false sense of security by the tendency of women with SC disease to maintain a normal total haemoglobin concentration. ${ }^{3}$ It remains of considerable concern that the prognosis for the fetus in pregnancies complicated by maternal sickle cell disease of all types has improved much less over the past 40 years than that observed for the mother. ${ }^{4}$ Furthermore, despite the relatively low coincidence of pregnancy and sickle cell disease in the United Kingdom four to six maternal deaths from this cause are regularly reported in each triennium. ${ }^{5}$

Our observations at Dulwich Hospital ${ }^{6}$ concur with those reported earlier from Jamaica $^{7}$ in finding no evidence of increased placental infarction to explain the impaired fetal growth and survival common in maternal sickle cell disease. The incidence of maternal red cells showing sickle deformity in the placenta is no greater than that seen in the placentas of women with sickle cell trait (who show no impairment of fetal wellbeing). In any case, few placental vessels are of a calibre that would be obstructed by sickled erythrocytes. We believe that the defective supply line to the fetus is more likely to result from impaired dynamics of the maternal circulation due to increased blood viscosity. 
We agree with Dr Serjeant that a controlled prospective assessment of prophylactic regimens of intensive blood transfusions during pregnancy in women with sickle cell disease is urgently required. The advantage of such treatment over equally careful supervision of the pregnancy but with a more conservative use of blood transfusions has been questioned. ${ }^{8}$ Multiple transfusions are not without certain dangers, including the induction of atypical red cell antibodies, which occurred in $14^{\circ}$ of the transfused patients in our United Kingdom series. ${ }^{4}$ If prophylactic transfusions are expected to have any appreciable impact on the rate of abortion and severe fetal growth retardation they would clearly need to be started much earlier than the suggested 28 weeks. In collaboration with colleagues at St Thomas's and certain other London hospitals we are about to start a study of the efficacy of transfusions that we hope will help to answer these questions.

SUSAN M TUCK

Maternity Department, John Radc

JOHN STUDD

Department of Obstetrics,

King's College Hospital,

London SE5

Rodeck CH, Campbell S. Sampling pure fetal blood by fetoscopy in second trimester of pregnancy. $\mathrm{Br} \mathrm{Med}$

Weatherall DJ, Higgs DR. Application of genetic engineering techniques to the study of the haemoglobinopathies. Hospital Update 1982;8:927-33.

${ }^{3}$ Diamond MP. Five cases of sickle-cell haemoglobin-C disease. Lancet 1959;ii:322-4

Tuck SM, Studd JWW, White JM. Pregnancy in sickle cell disease in the Lnited Kingdom. Br Obstet Gynaecol 1983;90:112

Department of Health and Social Security. Report on confidential enquiries into maternal deaths in England and W'ales. London: HMSO, 1972, 1975, 1979,
1982 .

Tuck S.M. Sickle cell disea
Hosp Med 1982;28:125-7.

Hosp Med 1982;28:125-7. , MacIver JE, Dixon $\mathrm{HG}$ Morrison JC, Blake PG, Reed CD. Therapy for the pregnant patient with sickle haemoglobinopathies : national focus. Am $\mathcal{J}$ Obstet Gynecol 1982;144: 268-9.

Morrison JC, Foster $\mathrm{H}$. Transfusion therapy in pregnant sickle cell disease patients. National Institutes of Health Consensus Developmen Conference. Ann Intern Med 1979;91:122-3.

\section{Medical treatment of portal hypertension and oesophageal varices}

SIR,-We would like comment on two points in the review by Dr Peter C Hayes and others (10 September, p 733) which appear erroneous. The authors said: "Unopposed alpha receptor activity on the hepatic artery producing vasoconstriction may, by the principle of reciprocity, reduce portal vascular resistance." The reduction of hepatic artery blood flow by propranolol is unlikely because $(a)$ the main intrinsic control of hepatic arterial perfusion is designed to hold total hepatic blood flow steady ${ }^{1}$ and $(b)$ in our experience in normal rats and in rats with portal hypertension due to portal vein stenosis propranolol slightly increased hepatic arterial blood flow in spite of a pronounced decrease in cardiac output. ${ }^{23}$ These arguments are reinforced by the absence of appreciable reduction in hepatic blood flow after administration of propranolol in normal rats as well as in rats with portal hypertension ${ }^{23}$ and in patients with portal hypertension due to cirrhosis. ${ }^{4}$

The relation between the reduction in hepatic blood flow produced by propranolol and the fall in the gradient between wedged and free hepatic venous pressures observed by Westaby and his colleagues is not our experience. ${ }^{5}$ This absence of correlation is not surprising since hepatic blood flow depends not only on portal venous perfusion but also on hepatic artery blood flow.

Paul Cales Alain BRAILlon DIDIER LEBREC

Unité de Recherches de

Physiopathologie Hepatique

(INSERM),

92118 Clichy, France

${ }^{1}$ Lautt WW. Relationship between hepatic blood flow nd overall metabolism: the hepatic arterial buffe rillon $P$, Bland Proc $1983,42: 1662-6$.

( in normal and portal hyper作

Cales P, Braillon A, Girod D, Lebrec D. Changes in splanchnic circulation in portal hypertensive rats meeting of the European Association for the Study of the Liver. Southampton, 1983

Lebrec D, Hillon P, Munoz C, Goldfarb G, Nouel O, Benhamou JP. The effect of propranolol on porta hypertension in patients with cirrhosis: a hemodynamic study. Hepatology $1982 ; 2: 523-7$.

Westaby D, Gimson AES, Bihari D, Croosley IR Williams R. Selective and non selective betablockade in the reduction of portal hypertension. Gut $1982 ; 23$ :A889.

\section{Royal Medical Benevolent Fund Christmas Appeal 1983}

SIR,-Once more the time has come for me to appeal to the medical profession to show its customary generosity at Christmas. The Royal Medical Benevolent Fund has always tried to give a gift to every one of its beneficiaries at this time. Each year the cost of this grows, but I am happy to say that the response of doctors and their families to this appeal always meets the need.

In 1982 our appeal raised the record sum of $£ 36138$, a clear indication that our supporters realise how much a little extra at Christmas means to those in need, especially the children. May I hope that the profession will show the same care for the less fortunate in 1983 ?

Contributions may be sent to treasurers or medical representatives of guilds of the Royal Medical Benevolent Fund or, marked "Christmas Appeal," to the Secretary, Royal Medical Benevolent Fund, 24 King's Road, Wimbledon, London SW 19 8QN.

\section{JOSEPHINE BARNES}

Royal Medical Benevolent Fund,

London SW19 8QN

\section{Manpower problems}

SIR,-In reply to Professor J E Lennard-Jones (27 August, p 618) Dr T J Bayley (24 September, p 913) points out, correctly, that a small reduction in the number of recognised senior registrars in medical gastroenterology will fail to improve the career prospects in that specialty because the age distribution of the existing consultants is so irregular. $\mathrm{Dr}$ Bayley adds, again correctly, that in specialties that have undergone rapid expansion in the consultant grade there are, inevitably, a high proportion of blocked posts for years to come. As a result the career prospect is poor, if it has to depend on retirement or death.

Let me support Dr Bayley by drawing attention to the fact that when $I$ had the privilege of addressing the executive sub- committee of the Central Committee for Hospital Medical Services on 21 January 1971 my evidence on manpower included graphs to illustrate exactly this point. In one I extrapolated from the number in post in 1958 and 1968 to project the number of retirement vacancies likely over the next 70 years (figure).

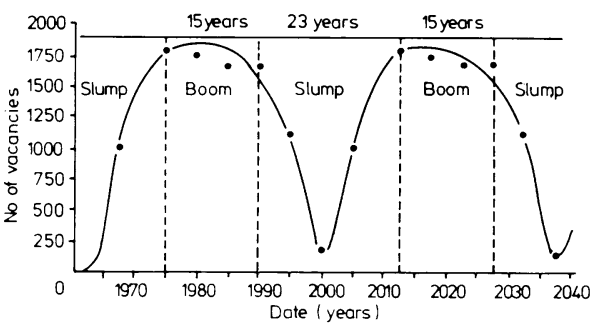

Projected number of retirement vacancies over the next 70 years.

F S A DORAN

Ledbury,

Herefordshire

\section{Risk to frontline medical care}

SIR,-You call for examples of the cuts in provision for the National Health Service causing hardship to patients (17 September, p 848). Two things in particular come to mind. Firstly, on a simple practical level GPs are not reimbursed for minor surgery either as items of service or for the materials used-for example, scalpels - and this is both a hindrance to patient care and, from the point of view of the Department of Health and Social Security, a foolishly short sighted economy.

Secondly, it has been drawn to my attention by my midwife that although she is a part timer and paid for about 20 hours a week, the scope of the task given her necessitates on occasions 40 hours' work, and she has been refused payment of overtime. It is said that she should take time in lieu, but the demands made on her in caring normally and effectively for her caseload are not congruent with this suggestion.

STEVEN D FORD

Burton Joyce,

\section{Babies' bottoms}

SIR,-Dr Eleanor Dafforn-Ierodiaconou (10 September, p 764) would have us wash our babies' bottoms with warm water and wrap them in disposable nappies. She bases these assertions on her clinical observations of olive skinned Greek babies. Oh for such clinical material. My own children, red haired and fair skinned, get nappy rashes at the smell of a disposable nappy. My wife, penny pincher that she is, gave away four dozen disposable nappies to friends whose babies had tougher skins.

Naked splendour is the best panacea for our children's nappy rashes, but the weather is usually too unkind and the carpet too precious. Failing this, towelling nappies and a barrier cream such as zinc are the only solution, for my children at least.

\section{DAVID IsAaCS}

Academic Department of Child

Health,

Queen Elizabeth Hospital for

London E2 8PS 